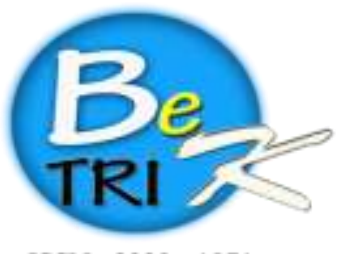

ISSN : $2339-1871$

\section{JURNAL ILMIAHBETRIK \\ Besemah Teknologi Informasi dan Komputer}

Editor Office : LPPM Sekolah Tinggi Teknologi Pagar Alam, Jn. Masik Siagim No. 75

Simpang Mbacang, Pagar Alam, SUM-SEL, Indonesia

Phone : $+62852-7901-1390$.

Email : betrik@sttpagaralam.ac.id | admin.jurnal@sttpagaralam.ac.id

Website: hitps:/ejournal.stipagaralam.ac id/index.php/betrik/index

\title{
RANCANG BANGUN WEBSITE MADRASAH AL - AZHAR KOTA PAGAR ALAM
}

\author{
Dedi Setiadi \\ Dosen Program Studi Teknik Informatika Sekolah Tinggi Teknologi Pagar Alam \\ JalanMasik Siagim No.75 Simpang Mbacang Kec.Dempo Tengah Kota Pagar Alam \\ Sur-el : dedisetiadi1212@gmail.com
}

\begin{abstract}
Abstrak: Madrasah Tsanawiyah ( MTs ) Al - Azhar kota Pagar Alam yang merupakan salah satu sekolah yang yang berada dibawah naungan Yayasan Islam Pagar Alam saat ini belum memiliki website sendiri sebagai media untuk menyampaikan informasi dan untuk mempromosikan sekolah kepada masyarakat. Dibangunnya website sekolah MTs Al - Azhar, diharapkan dapat memudahkan masyarakat dalam mendapatkan informasi yang dibutuhkan tentang sekolah. Website MTs Al - Azhar dibangun menggunakan metode pengembangan sistem web engineering yang terdiri dari tahapan customer communication, planning, modeling, construction dan deployment, desain rancangan sistem menggunakan Unified Modeling Language ( $U M L$ ). Sedangkan aplikasi yang digunakan untuk merancang sistem yaitu Axure Pro untuk membuat story board antar muka, Adobe Dreamweaver CS sebagai text editors dalam penulisan program, bahasa pemrogaman $H T M L$ dan $P H P$, dalam pengolahan database-nya menggunakan $M y S Q L$ dan Web Server menggunakan Apache. Pengujian sistem menggunakan black box testing dan usability testing dengan nilai akhir 3,85 yang berarti pengguna menyatakan bahwa website ini bisa mempermudah pihak sekolah untuk menyampaikan informasi dan juga mempermudah pihak - pihak yang ingin mendapatkan informasi dengan cepat, serta bisa diakses kapan saja dan dimana saja
\end{abstract}

Kunci Utama: Website, Madrasah Tsanawiyah, $P H P \& M y S Q L$

\begin{abstract}
Madrasah Tsanawiyah (MTs) Al-Azhar Pagar Alam city which is one of the schools under the auspices of Pagar Alam Islamic Foundation currently does not have its own website as a medium to convey information and to promote the school to the community. The construction of the school website of MTs AlAzhar, is expected to facilitate the public in getting the required information about the school. The website of MTs Al-Azhar is built using web engineering system development method which consists of customer communication, planning, modeling, construction and deployment stage, design of system design using Unified Modeling Language (UML). While the application used to design the system that is Axure Pro to create a story board interface, Adobe Dreamweaver CS as a text editors in writing programs, programming languages HTML and PHP, in the database processing using MySQL and Web Server using Apache. Testing the system using black box testing and usability testing with the final value of 3.85 which means the user states that this website can facilitate the school to convey information and also facilitate the parties who want to get information quickly, and can be accessed anytime and anywhere
\end{abstract}

Keywords : Website, Madrasah Tsanawiyah, PHP \& MySQL

\section{PENDAhULUAN}

Teknologi informasi dan komunikasi sekarang ini sudah semakin berkembang, kebutuhan akan sebuah informasi yang berkualitas sangatlah diperlukan. Perkembangan teknologi ini mempengaruhi kehidupan sosial masyarakat yang terdiri dari berbagai macam budaya serta tingkat sosial yang ada. Internet adalah salah satu media yang digunakan dalam dunia teknologi informasi dan komunikasi. Internet merupakan suatu perpustakaan besar yang menyimpan berbagai data dan informasi yang 
dapat berupa teks, audio, video dan lain - lain dalam bentuk media elektronika. (Sulaini, Internet Untuk Pemula, 2014) Saat ini internet menjadi bagian dari kehidupan masyarakat modern, dikarenakan mudahnya akses internet maka dari hari ke hari pengguna internet terus bertambah. Dan juga dengan keberadaan internet maka penyebaran informasi akan semakin cepat dan mudah, dan juga internet dapat dimanfaatkan di berbagai bidang kehidupan, salah satunya di bidang pendidikan.

Bagi sebuah instansi pendidikan saat ini yang memiliki banyak informasi yang harus selalu disampaikan kepada siswa, guru dan juga masyarakat umum, sangat tepat jika penyampaian informasi tersebut disampaikan dengan memanfaatkan internet untuk memudahkan dalam penyebaran informasi tersebut, dan media aplikasi yang digunakan untuk menyebarkan informasi tersebut yaitu dengan menggunakan website. Website atau juga sering disebut dengan situs merupakan kumpulan beberapa halaman web yang berguna untuk menampilkan informasi teks, gambar, suara, animasi atau gabungan dari semuanya yang dijalankan dari satu halaman web domain. (Nilasari, 2014) Dan saat ini website dapat dengan mudah diakses menggunakan berbagai perangkat yang terhubung dengan internet, kapan saja dan dimana saja, termasuk di kota Pagar Alam.

Masyarakat di kota Pagar Alam saat ini, sudah banyak yang memanfaatkan internet, baik melalui perangkat komputer ataupun dengan menggunakan ponsel, dalam mencari dan mendapatkan informasi - informasi yang dibutuhkan, tidak terkecuali informasi tentang dunia pendidikan. Penggunaan teknologi internet dalam hal ini yaitu website merupakan terobosan baru di bidang pendidikan dalam penyampaian informasi dan sebagai media promosi sekolah kepada masyarakat, oleh sebab itu dengan adanya website sekolah sangat membantu masyarakat dalam mendapatkan informasi tentang sekolah dan juga memudahkan pihak sekolah dalam menyampaikan informasi kepada masyarakat.

MTs Al - Azhar kota Pagar Alam, saat ini dalam penyampaian informasi yang ada masih secara konvensional yaitu secara lisan dan tulisan melalui surat undangan, brosur, spanduk atau baliho, baik itu kepada lingkungan sendiri atau lingkungan umum belum menggunakan media teknologi informasi. Dan sangat disayangkan sekali karena di MTs Al - Azhar saat ini sudah memiliki koneksi internet yang baik dengan menggunakan jaringan wifi, tetapi saat ini MTs Al - Azhar belum memiliki website sendiri sebagai media untuk menyampaikan informasi dan untuk mempromosikan sekolah kepada masyarakat. Selama ini calon siswa dan orang tua murid harus datang ke sekolah untuk mengetahui lebih banyak informasi tentang Madrasah Tsanawiyah Al - Azhar kota Pagar Alam. Sebagai salah satu lembaga pendidikan sangat perlu dibangun website sebagai terobosan baru dalam menyampaikan informasi sehingga bisa memudahkan masyarakat dalam mendapatkan informasi yang dibutuhkan tentang sekolah, dengan cepat dan mudah serta bisa di akses kapan saja dan dimana saja serta sudah saatnya lembaga pendidikan madrasah bersaing dengan sekolah - sekolah lain memiliki website sendiri. 
Dan juga dengan dibangunnya website di Madrasah Tsanawiyah Al - Azhar kota Pagar Alam, maka akan sangat membantu pihak sekolah dalam menyampaikan informasi kepada user, serta informasi yang ada dikelola dan disimpan didalam suatu sistem sehingga jika sewaktu - waktu informasi tersebut nantinya di butuhkan oleh pihak - pihak yang berkepentingan, maka akan dengan mudah untuk mencarinya di dalam sistem tersebut.

Berdasarkan uraian di atas maka penulis melakukan penelitian, dengan mengambil judul “ Rancang Bangun Website Madrasah Tsanawiyah Al - Azhar Kota Pagar Alam. Diharapakan Madrasah Tsanawiyah Al - Azhar memiliki media yang lebih baik yang digunakan untuk penyebaran informasi yang ada kepada siswa, guru dan masyarakat umum.

\section{METODE PENELITIAN}

\subsection{Metode Pengumpulan Data}

\section{a. Interview ( Wawancara )}

Teknik ini digunakan sebagai studi pendahuluan untuk menemukan permasalahan yang akan diteliti dan jika peneliti ingin melakukan penelitian yang lebih mendalam melalui responden. (Sugiyono, 2011) Dalam penelitian yang dilakukan dalam pengumpulan data dan informasi yang dibutuhkan, ditanyakan langsung kepada kepala sekolah dan bagian Tata Usaha yang sangat berperan dalam pengelolaan data dan informasi yang berada di Madrasah Tsanawiyah Al - Azhar kota Pagar Alam.

\section{b. Observasi ( Pengamatan langsung )}

Menurut Sutrisno Hadi ( 1986 ) dari buku yang ditulis oleh (Sugiyono, 2011) menjelaskan bahwa observasi merupakan suatu proses yang kompleks yang tersusun dari berbagai proses biologis dan psikologis, diantaranya yaitu proses - proses pengamatan dan ingatan. pada penelitian yang dilakukan pengumpulan data dan informasi didapat dengan cara melakukan survey atau melihat langsung keadaan dan kondisi Madrasah Tsanawiyah Al - Azhar kota Pagar Alam serta melihat sistem yang sedang berjalan.

\section{c. Dokumentasi}

Teknik ini merupakan pelengkap dari penggunaan observasi dan wawancara, yang menjadikan hasil dari observasi dan wawancara akan lebih kredibilitas dan dapat dipercaya. Hal yang dilakukan untuk mendapatkan data berupa berkas - berkas laporan, data siswa, data guru yang di gunakan untuk mengetahui hal - hal yang harus dilaporkan bagian Tata Usaha kepada Kepala Sekolah, serta untuk mengetahui kondisi Madrasah Tsanawiyah Al - Azhar kota Pagar Alam.

\section{d. Study Pustaka}

Untuk melengkapi kekurangan - kekurangan data yang di butuhkan melalui metode wawancara dan observasi maka pengumpulan data juga dilakukan dengan mengambil data dan informasi dari sumber hasil karya tulis orang lain seperti buku, jurnal ilmiah dan juga mengambil dari artikel yang berada dihalaman web.

\subsection{Landasan Teori}

\subsubsection{Website}

Website atau disebut dengan situs merupakan kumpulan beberapa halaman web yang berguna untuk menampilkan informasi teks, gambar, suara, animasi atau gabungan dari semuanya yang dijalankan dari satu halaman web domain . (Nilasari, 2014) Selanjutnya menurut sifatnya, website dibedakan menjadi dua jenis yaitu :

a. Website Statis 
Website statis merupakan website yang sifatnya tetap atau tidak berubah - ubah isi dan tampilnya, dalam pembuatan website ini menggunakan bahasa pemrogaman HTML dan website ini tidak menggunakan database. Website ini biasanya digunakan sebagai web pribadi dan organisasi.

\section{b. Website Dinamis}

Website dinamais merupakan jenis website yang isi atau kontennya bisa bierubah - ubah setiap saat. Bahasa pemrogaman yang digunakan yaitu PHP, dan website ini menggunakan database. Contoh dari website ini yaitu web berita.

\subsubsection{Internet}

Internet adalah sistem global dari jaringan komputer di seluruh dunia yang terhubung menggunakan standar Internet Protocol Suite ( $T C P / I P$ ). Sedangkan dari segi ilmu pengetahuan internet dapat diartikan sebagai sebuah perpustakaan besar yang menyimpan berbagai data dan informasi yang dapat berupa teks, audio, video dan lain - lain dalam bentuk media elektronika. (Sulaini, Internet Untuk Pemula, 2014)

\subsubsection{Basis Data}

Basis Data atau Database merupakan kumpulan data yang saling berelasi yang disusun, diorganisaikan serta disimpan secara sitematik dalam suatu media penyimpanan komputer yang mengacu pada metode - metode tertentu sehingga dapat diakses secara cepat mudah menggunakan program atau aplikasi komputer untuk memperoleh data dari basis data tersebut. (Ichwan, 2011)

\subsubsection{Web Browser}

Web Browser merupakan suatu program komputer yang memiliki fungsi sebagai media untuk menampilkan dokumen - dokumen web dalam format HTML. (Arief, 2011) Web browser yang populer dan yang biasa kita gunakan diantaranya yaitu mozilla firefox, google chrome, opera.

\subsubsection{Web Server}

Web Server merupakan suatu program aplikasi yang berfungsi sebagai tempat menyimpan dokumen - dokumen web. Contoh web server yang biasa dipakai yaitu web server Apache yang mendukung PHP, web server Microsoft Internet Information Service ( IIS ), yang mendukung ASP dan PHP. (Arief, 2011)

\subsection{Rancangan Sistem}

a. Use Case aktor Admin

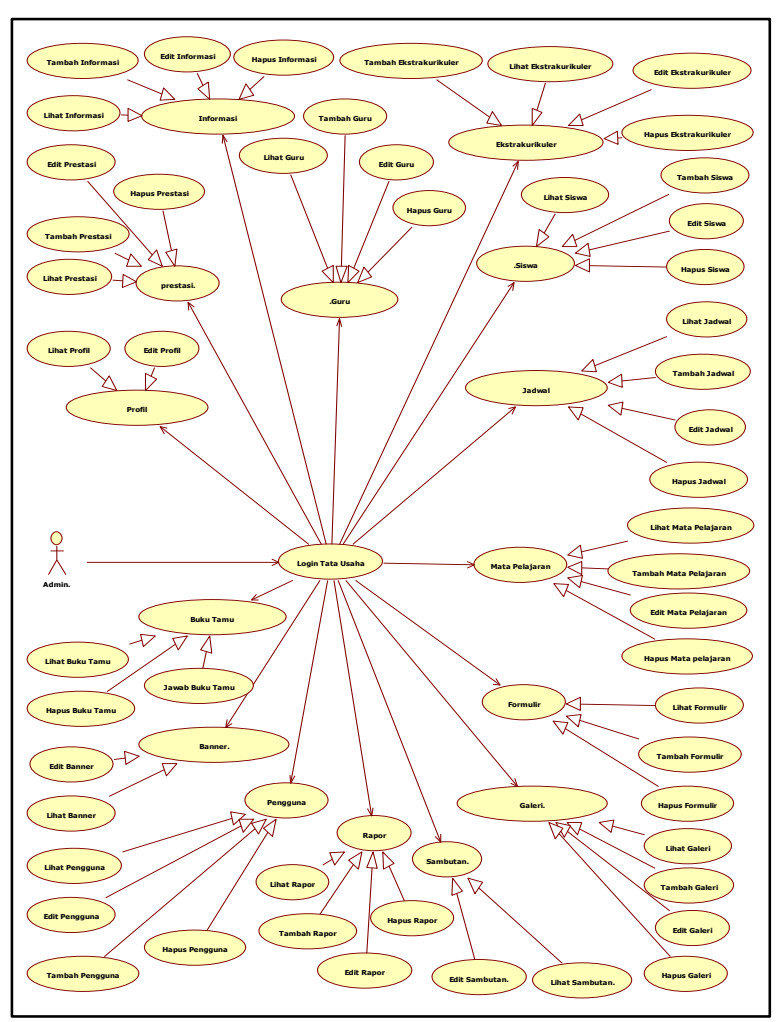

Gambar 1. Use Case Admin 
b. Class Diagram

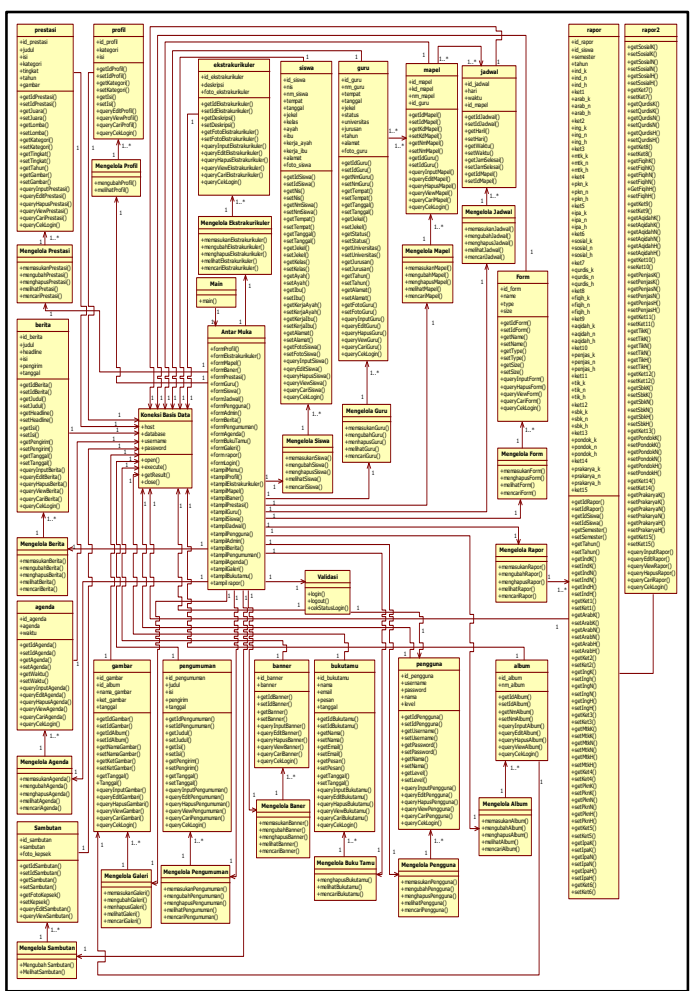

Gambar 2. Class Diagram

c. Story Board

a) Desain Halaman Utama

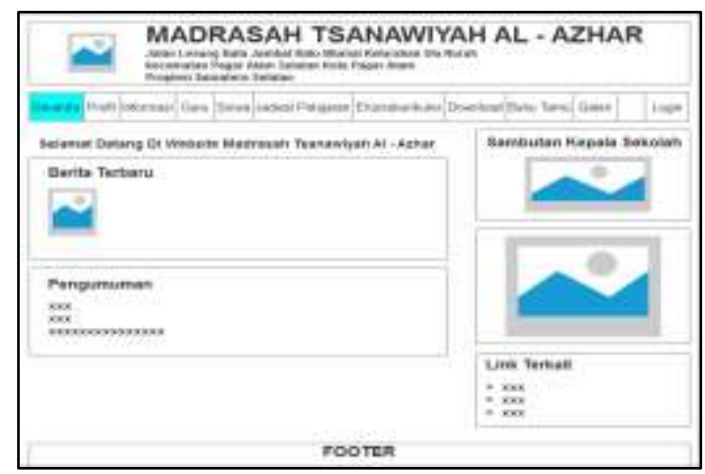

Gambar 3. Desain Halaman Utama

b) Desain Halaman Sejarah

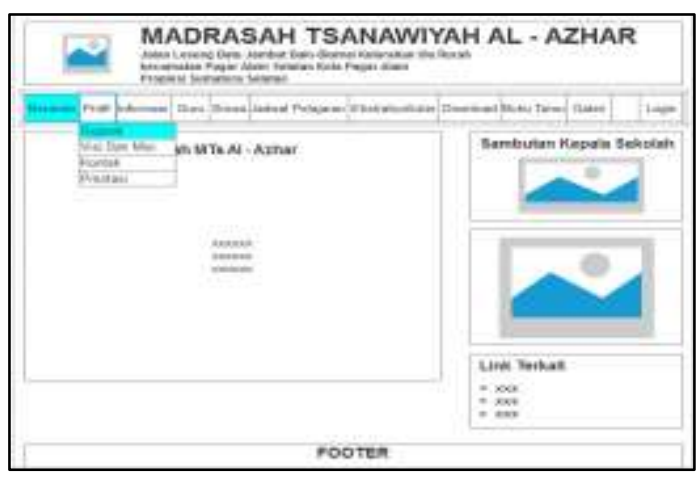

Gambar 4. Desain Halaman Sejarah c) Desain Halaman Guru

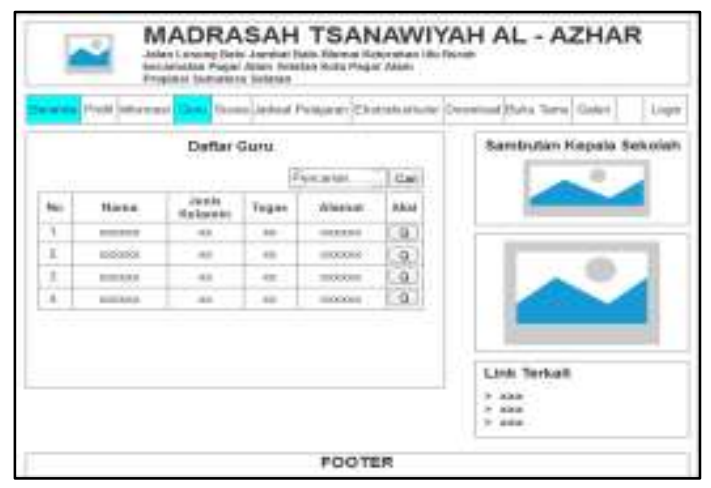

Gambar 5. Desain Halaman Guru

d) Desain Halaman Ekstrakurikuler

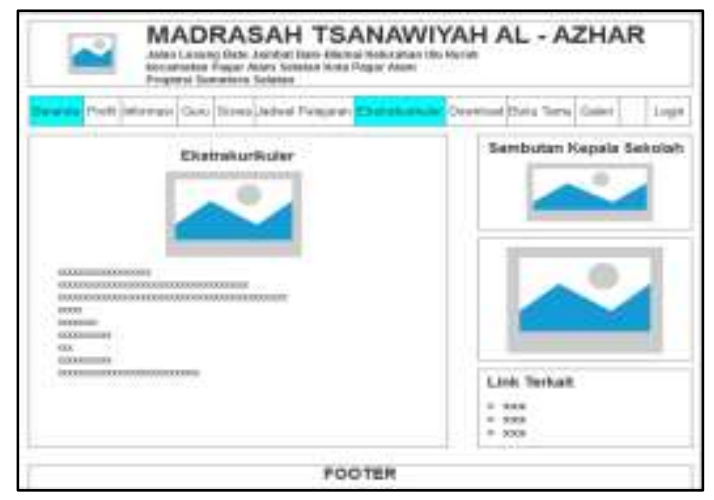

Gambar 6. Desain Halaman Ekstrakurikuler

e) Desain Halaman Login

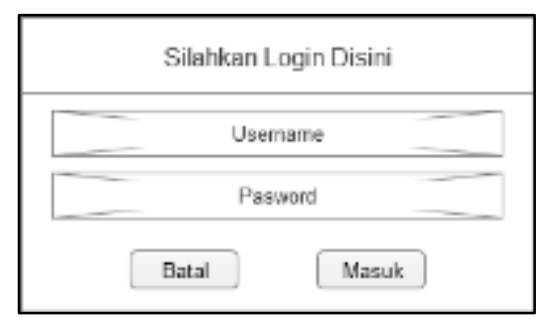

Gambar 7. Desain Halaman Login

f) Desain Halaman Admin

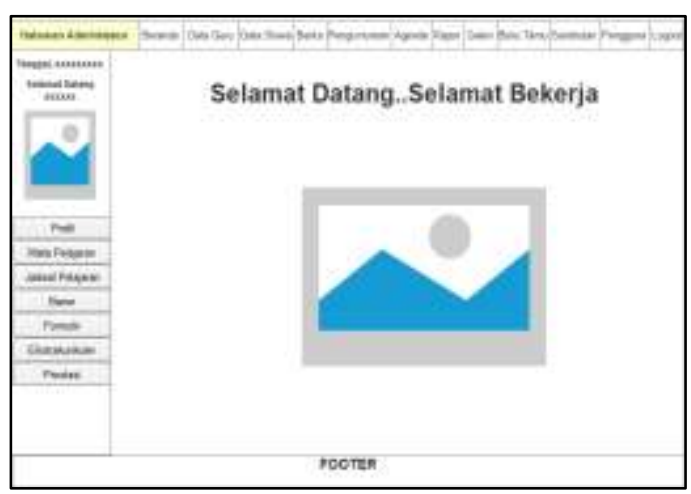

Gambar 8. Desain Halaman Utama

\section{Admin}


g) Desain Halaman Profil

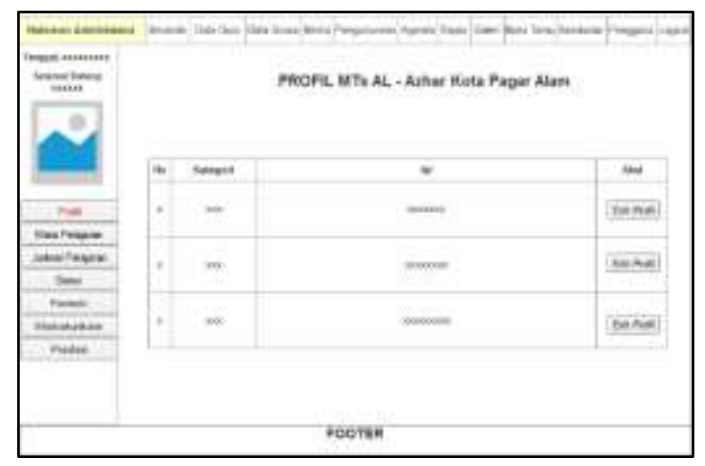

Gambar 9. Desain Halaman Profil

h) Desain Halaman Daftar Guru

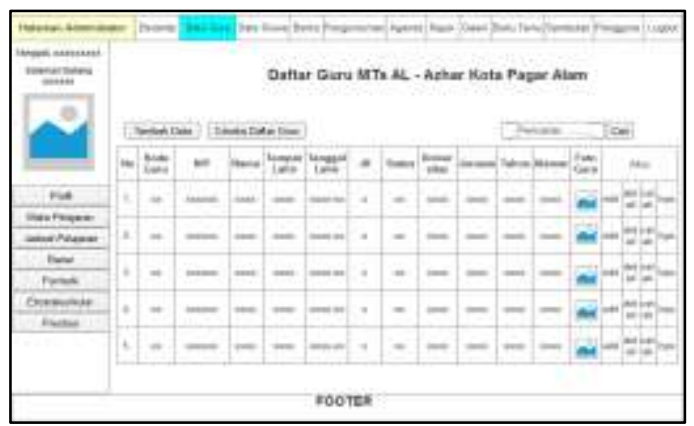

Gambar 10. Desain Halaman Guru

i) Desain Halaman Input Data Guru

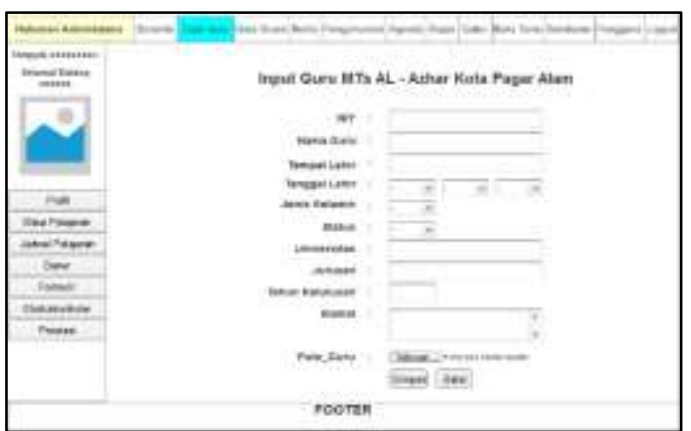

Gambar 11. Desain Halaman Input Data Guru

j) Desain Halaman Edit Data Guru

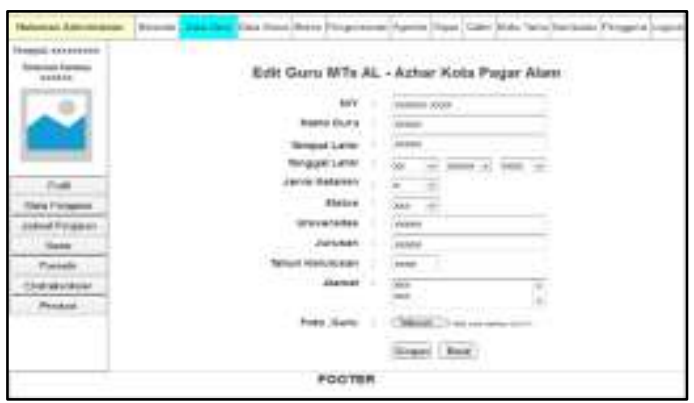

Gambar 12. Desain Halaman Edit Data Guru k) Desain Halaman Berita

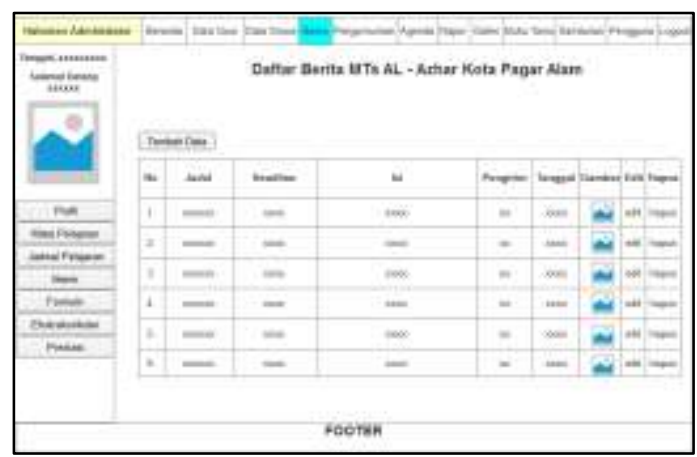

Gambar 13. Desain Halaman Berita

1) Desain Halaman Input Berita

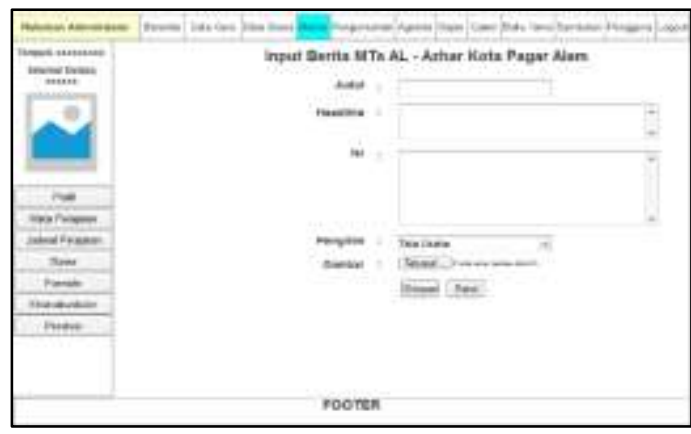

Gambar 14. Desain Halaman Input

Berita

m) Desain Halaman Baner

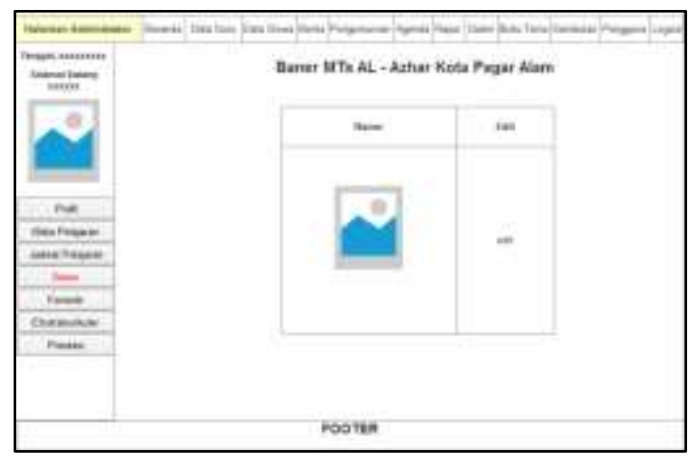

Gambar 15. Desain Halaman Baner

n) Desain Halaman Edit Baner

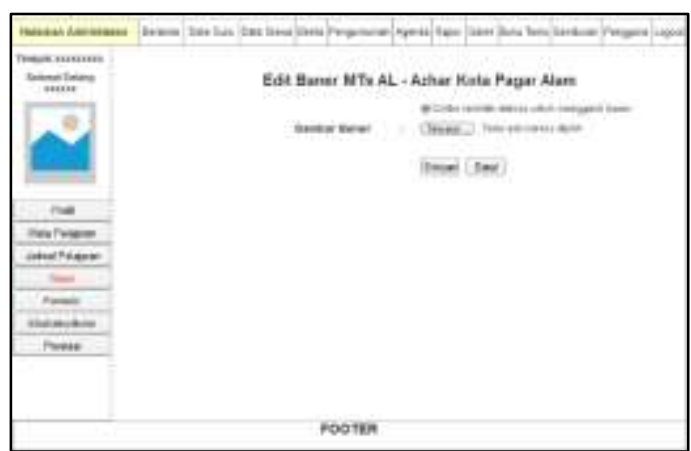

Gambar 16. Desain Halaman Edit Baner 


\section{HASIL DAN PEMBAHASAN}

\subsection{Hasil}

a. Tampilan Halaman Utama

Halaman ini adalah halaman yang muncul pertama kali ketika masuk ke website MTs Al Azhar, yang menampilkan ucapan selamat datang.

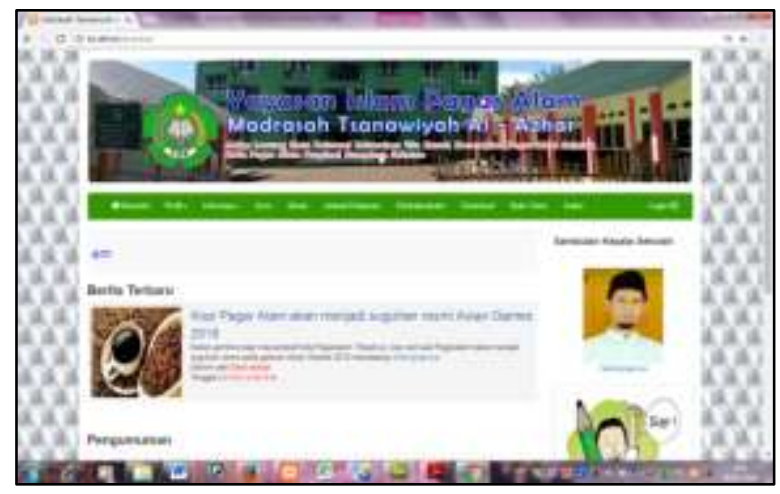

\section{Gambar 17. Halaman Depan}

b. Tampilan Halaman Sejarah

Halaman ini menampilkan tentang sejarah singkat dari MTs Al - Azhar kota Pagar Alam.

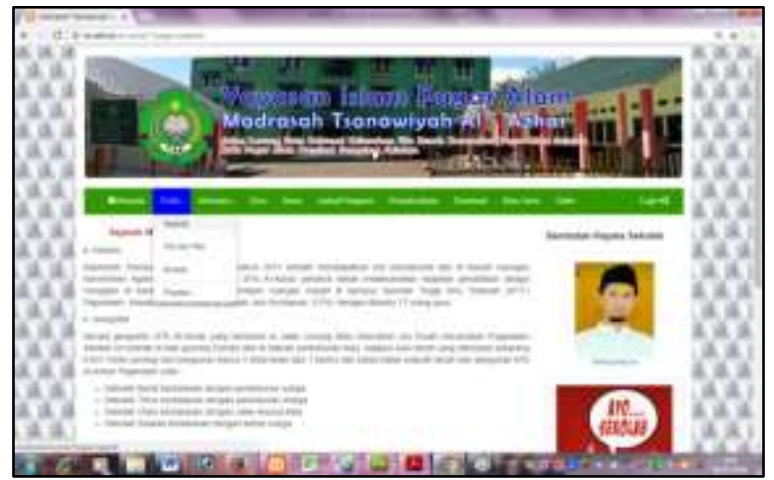

Gambar 18. Halaman Sejarah

c. Tampilan Halaman Guru

Halaman ini menampilkan daftar guru MTs Al - Azhar kota Pagar Alam, beserta tombol detail dimana ketika user meng-klik tombol tesebut maka akan tampil biodata lengkap dari guru yang dipilih.

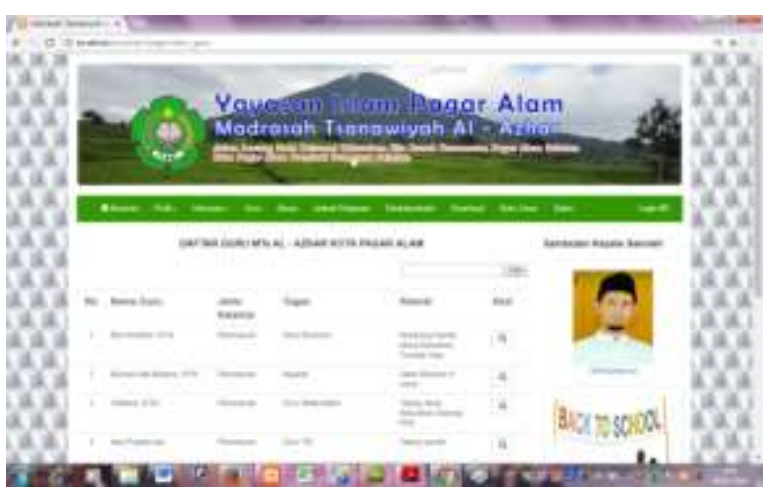

\section{Gambar 19. Halaman Guru}

d. Tampilan Halaman Ekstrakurikulaer

Halaman ini menampilkan daftar dari ekstrakurikuler yang ada pada MTs Al - Azhar kota Pagar Alam, yang terdiri dari foto ekstrakurikuler dan deskripsi atau keterangan dari ekstrakurikuler.

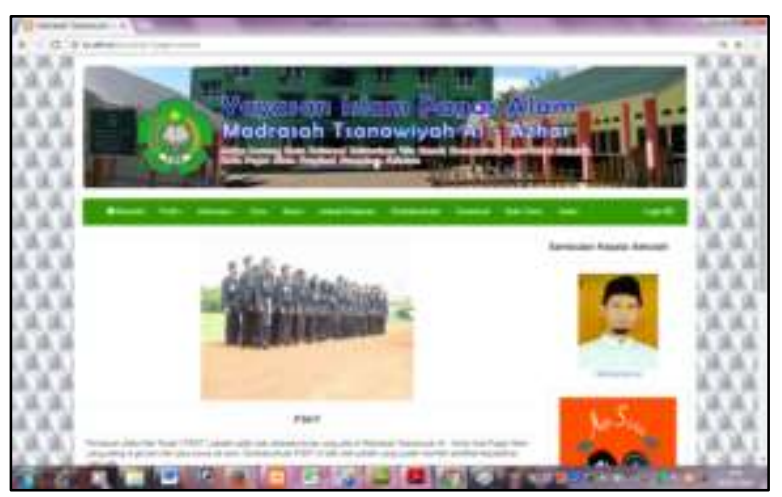

Gambar 20. Halaman Ekstrakurikuler

e. Tampilan Halaman Download

Halaman ini menampilkan file - file yang di upload oleh admin ataupun tata usaha.

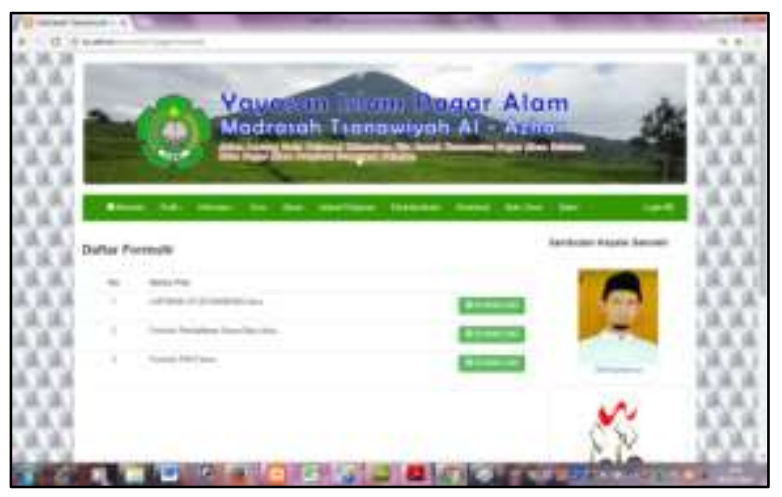

Gambar 21. Halaman Download 
f. Tampilan Halaman Utama Admin

Halaman ini adalah halaman yang tampil setelah user melakukan login sebagai admin.

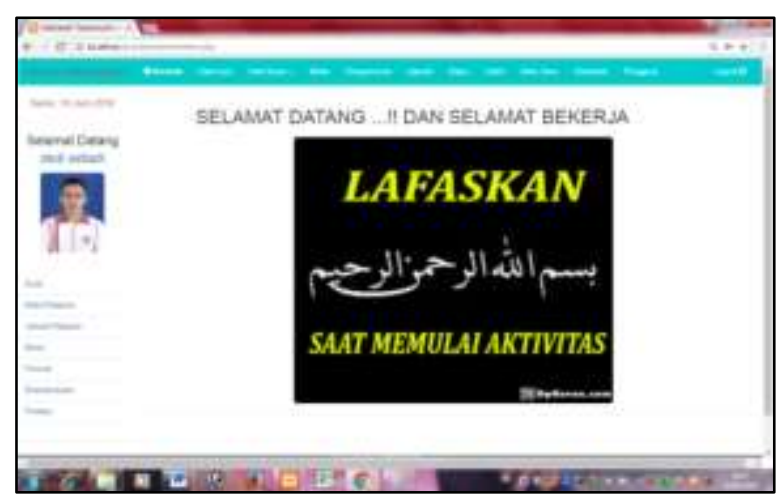

\section{Gambar 22. Halaman Utama Admin}

g. Tampilan Data Siswa

Halaman ini berisi data siswa MTs Al Azhar kota Pagar Alam.

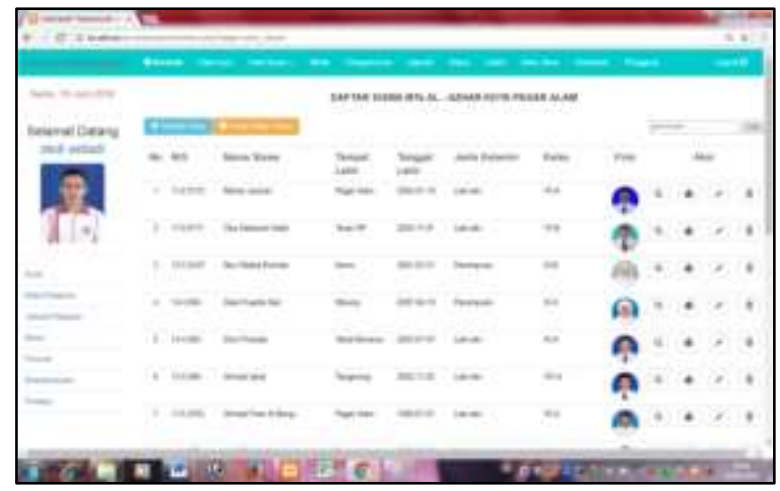

Gambar 23. Halaman Input Data Siswa

h. Tampilan Input Data Siswa

Halaman ini tampil ketika user memilih tombol tambah data pada halaman data siswa. Halaman ini merupakan form yang bisa diisi oleh user.

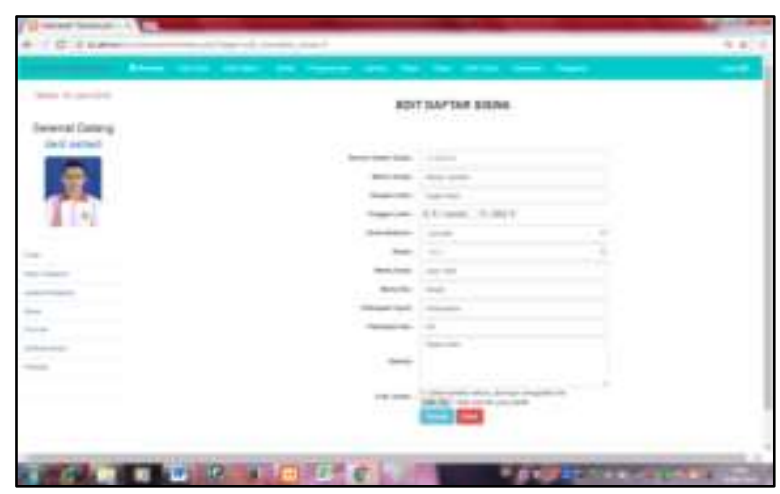

Gambar 24. Halaman Input Data Siswa i. Tampilan Cetak Data Siswa

Halaman ini tampil ketika user memilh tombol cetak data siswa, yang merupakan tampilan print preview data siswa yang akan dicetak.

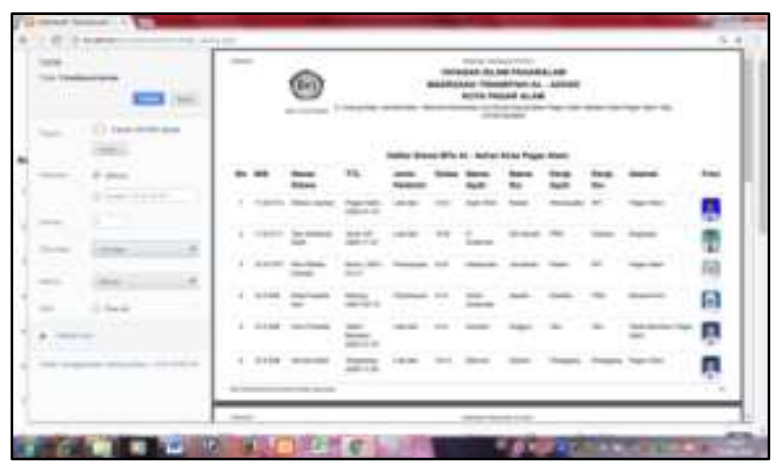

\section{Gambar 25. Cetak Data Siswa}

j. Tampilan Biodata Siswa

Halaman ini tampil ketika user memilih tombol detail, yang merupakan tampilan biodata lengkap siswa yang dipilih.

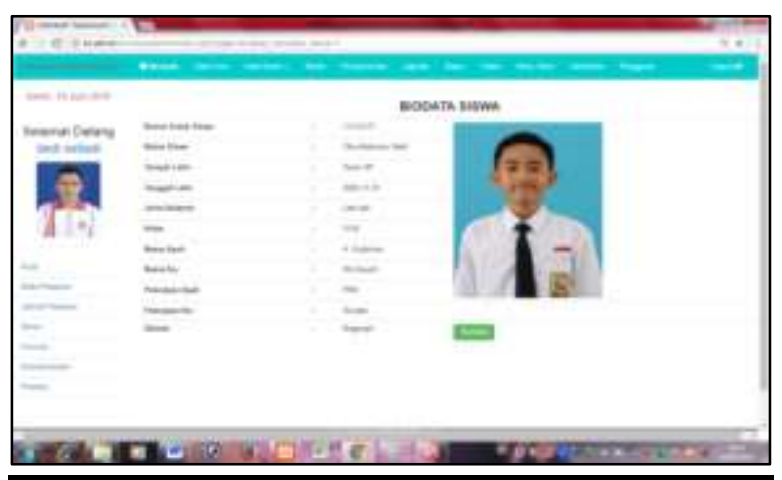

Gambar 26. Halaman Biodata Siswa

k. Tampilan Halaman Berita

Halaman ini tampil ketika user memilih menu navigasi berita yang berisi data berita yang tersimpan didalam database.

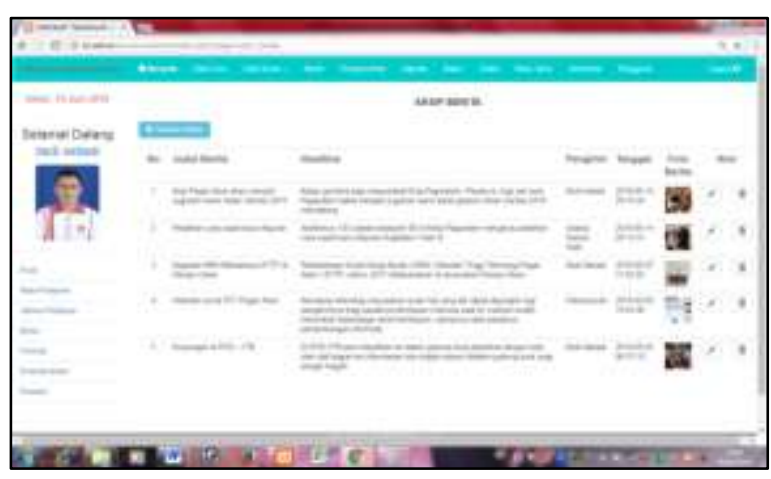

Gambar 27. Halaman Berita 
1. Tampilan Cetak Rapor

Halaman ini merupakan tampilan print preview data nilai rapor siswa yang akan dicetak.

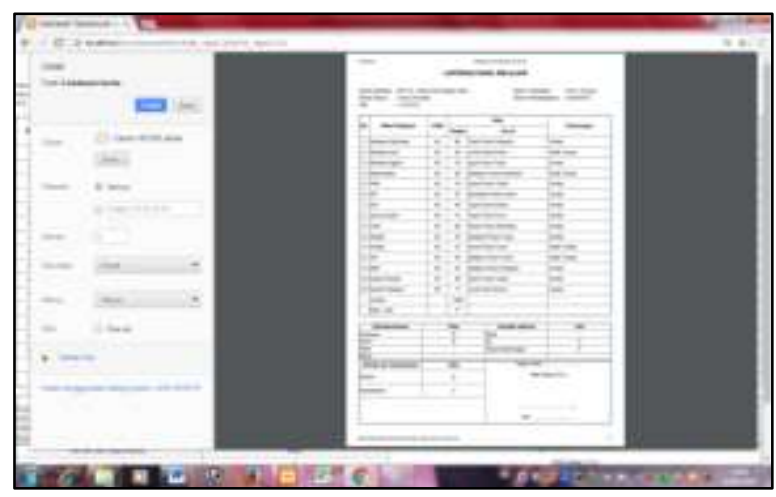

Gambar 28. Halaman Cetak Rapor

\subsection{Pembahasan}

Setelah website jadi atau selesai dibuat, selanjutnya dilakukan pengujian, untuk mengetahui dan memastikan bahwa website yang di buat terbebas dari kesalahan yang bisa saja terjadi dalam pembuatannya. Dalam penelitian ini penulis menggunakan dua metode black box testing dan usability testing.

\section{a. Black Box Testing}

Black box testing yaitu pengujian untuk mengetahui fungsi - fungsi, masukan dan keluaran didalam program apakah sudah berjalan sesuai dengan yang diharapkan atau belum, (Rosa A.S., 2014)

\section{b. Usability Testing}

Hasil penilaian dari responden tentang website MTs Al - Azhar dengan menggunakan metode usability testing, yaitu :

\section{a) Learnability}

Dalam aspek learnability dengan nilai dari tiga pertanyaan yang diajukan, memiliki rata - rata 3,84 setelah dibulatkan menjadi 4. Maka dapat disimpulkan bahwa website MTs Al - Azhar mudah dalam mengoprasikannya.

b) Efficiency
Dalam aspek efficiency dengan nilai dari dua pertanyaan yang diajukan, memiliki rata - rata 3,93 setelah dibulatkan menjadi 4. Maka dapat disimpulkan bahwa menu dan fungsi yang ada pada website MTs $\mathrm{Al}$ - Azhar sederhana atau tidak ribet.

c) Memorability

Dalam aspek memorability dengan nilai dari dua pertanyaan yang diajukan, memiliki rata - rata 3,73 setelah dibulatkan menjadi 4. Maka dapat disimpulkan bahwa menu dan fungsi yang ada pada website MTs $\mathrm{Al}$ - Azhar mudah di ingat oleh pengguna.

d) Errors

Dalam aspek errors dengan nilai dari satu pertanyaan yang diajukan, memiliki rata - rata 3,67 setelah dibulatkan menjadi 4. Maka dapat disimpulkan bahwa website MTs Al - Azhar yang telah dibuat sedikit terjadi kesalahan atau errors menu dan fungsinya.

\section{e) Satisfaction}

Dalam aspek satisfaction dengan nilai dari dua pertanyaan yang diajukan, memiliki rata - rata 4,10 setelah dibulatkan menjadi 4. Maka dapat disimpulkan bahwa pengguna merasa puas dengan website MTs Al - Azhar kota Pagar Alam dan perlu untuk diimplementasikan website tersebut.

Gambar 4. 1: Gambar grafik usability testing

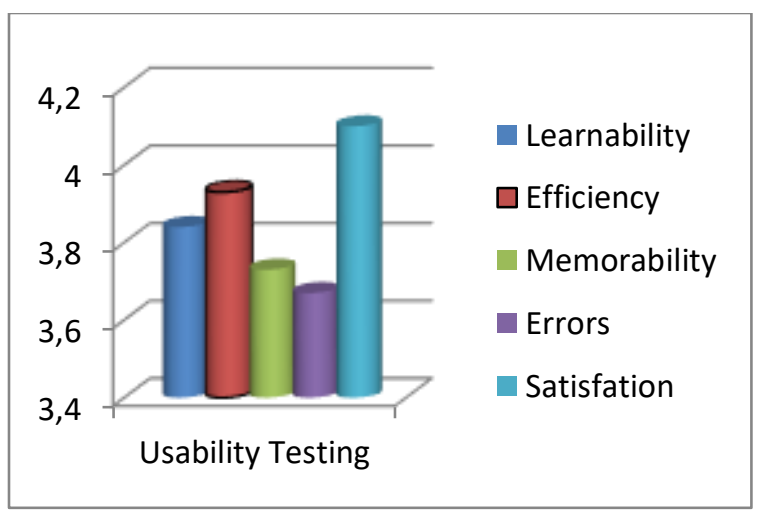




\section{SIMPULAN}

Dengan dibangunnya website MTs Al - Azhar kota Pagar Alam memberikan manfaat :

a. Menjadi terobosan baru dalam penyampaian informasi karena bisa mempermudah pihak sekolah untuk menyampaikan informasi dan juga mempermudah pihak - pihak yang ingin mendapatkan informasi dengan cepat, serta bisa diakses kapan saja dan dimana saja;

b. Bisa digunakan sebagi media untuk mempromosikan MTs Al - Azhar dan juga meningkatkan grade atau nilai lebih dari masyarakat terhadap MTs Al - Azhar kota Pagar Alam;

c. Website ini bisa menjadi media resmi MTs Al - Azhar kota Pagar Alam dalam mempublikasikan profil sekolah ke masyarakat umum.

\section{DAFTAR RUJUKAN}

Arief, M. R. (2011). Pemrogaman Web Dinamis Menggunakan PHP Dan MySQL. Yogyakarta: Andi Offset.

Ichwan, M. (2011). Pemrogaman Basis Data Delphi 7 \& MySQL. Bandung: Informatika.

Marlena, N., \& Sasongko, D. (2012). Pembuatan Website Profil Pada sekolah Menengah Pertama ( SMP ) Negeri 2 Kartasura. Jurnal Speed.

Mukti, YI, D. (2017). Sistem Informasi Madrasah Aliyah Negeri Kota Pagar Alam Berbasis Web. IJCS STMIK Indonesia, Padang

Nilasari, S. (2014). Jago Membuat Website Gratis \& Cepat. Jakarta: Dunia Komputer.
Sugiyono. (2011). Metode Penelitian Kuantitatif Kualitatif Dan $R \& D$. Bandung: $\mathrm{Cv}$ Alfabeta.

Suhartanto, M. (2012). Pembuatan Website Sekolah Menengah Pertama Negeri 3 Delangu dengan Menggunakan PHP dan MySQL. Journal Speed-Sentra Penelitian Engineering dan Edukasi.

Sulaini, I. (2014). Internet Untuk Pemula. Yogyakarta: Deepublish.

Sutarman. (2003). Membangun Aplikasi Web dengan PHP dan MySQL. Yogyakarta: Graha Ilmu.

Utomo, B., \& Bakara, C. (2013). Pembuatan Web Profil Sekolah Menengah Pertama Negeri 1 Ngrampal Dengan Menggunakan PHP Dan MySQL. Seminar Riset Unggulan Nasional Informatika dan Komputer FTI UNSA. 